\title{
The Realistic Dilemma and Reason of Public Participation in
}

\section{Social Governance}

\author{
Hai Hu \\ College of Marxism, Sichuan Agricultural University, Chengdu City 611130, China \\ E-mail: huhai119@163.com
}

Keywords: social governance; public participation; dilemma; reason

\begin{abstract}
In recent years, our country in the public participation in social governance of many effective exploration, but the current our country public in social governance still exist in the public to participate in social governance, lack of necessary legal protection and public participation in the construction of social governance system lag, public participation in social governance by the government's social management constraints and other factors influence, the public is not sufficient to participate in the social governance.
\end{abstract}

\section{Introduction}

With the development of social problems continue to increase and the party and the government to the public participation in social governance attention will continue to improve, the public to participate in the implementation of the democratic rights of social governance has become the consensus of the whole society, objectively promoted the Chinese public to participate in the rapid development of social governance. However, due to the impact of many factors, the Chinese public participation in social governance is still faced with many difficulties.

\section{The realistic dilemma of public participation in social governance}

The lack of legal system to safeguard public participation in social governance. For the public service is an important purpose of social governance, the real master of social governance should be the public. The public should also have the right to participate in the social governance of the vital interests of their own, and to express their wishes, opinions or suggestions in the management of public affairs. With the economic globalization and the deepening of China's reform and opening up, as a key link in the construction of socialist democratic politics in China, public participation of social governance has also has become the focus of attention from the theorists and the public, but our country has not been established in conformity with a set of legal system. The existing public participation in social governance of the main government departments in order to solve the social problems and try to promote, there is no formation of specific legal provisions. At present, our country has issued a lot of laws and regulations of public participation and the construction of service-oriented government, but these laws and regulations on public participation in social governance subject, scope, way, content and approaches are not clearly defined, has not formed a complete legal system, and the lack of public participation in violation of supervision and restriction and punishment the provisions of the social governance, not restricting governments at 
all levels to implement public participation, the implementation of public participation, some government workers lack the incentive to protect, which led to China's public participation in social governance has no legal regulations, public participation in social governance rights are not implemented, the enthusiasm of public participation in social governance by contusion.

Public participation in social governance system construction lags behind. At present, our country is in the initial stage of strengthening and innovating social governance, the system of public participation in social governance has not been formed, the mechanism of public participation in social governance is not perfect, not mature. It is not enough to study the ownership of social governance, the means of social governance, the object of social governance, the way of social governance, and so on. It has not formed a scientific and reasonable theoretical system. This is due to the impact of the planned economic system, in a long period of time, the Chinese government is a social and public affairs manager, for the community to provide public goods, social control". This has led to the government's positioning for social governance is unknown, unclear responsibilities, the government should assume the role of social governance and management responsibilities without a clear understanding of. At the same time, the existing social public decision-making mechanism of the lack of necessary supervision system and evaluation system, which leads to the voice of the public and the interests of the demands of difficult in public decision reflected, when the public's inability to pass system correct demands, it will damage the public interests, extremely easy to cause the antithesis of the public and the government, and lead to mass incidents, resulting in social instability. It can be seen that the existing social management system has been unable to meet the public's growing desire to participate, has hindered the development of China's public participation in social governance.

Public participation in social governance by the constraints of government functions. Affected by the planned economic system, the government of social management still exist in the centralized leadership, to the society "control", cause of public participation in government the problem of the lack of understanding of the system and overall, of the government in social governance role, scope and role orientation do not have a clear grasp of, causing public participation cannot be carried out in an orderly manner so as to affect the effect of public participation, and the impact of the social governance of normal. The main form in the past, the government centralized management, the social groups and citizens to participate in social governance is limited in a narrow range, lack of vitality of social governance, the management of public affairs is mainly rely on the government's administrative behavior, which led to the status of the masses of the people are the masters of the country is restricted, the civil power is also difficult to in social governance play should have the role of inhibition for the general public to participate in the enthusiasm of social governance. Therefore, the government should change the traditional idea of social governance, change the past unified social governance mode of management main body, the establishment of multi subject's participation in social management mode. If the government is going to all social public affairs are incorporated into its social management functions, it will cause the government's "Absence" and "offside", it will cause the government of the tube of the tube is no good, the tube is not to tube, which will inevitably lead to of public participation in government social governance constraints.

\section{Analysis on the causes of public participation in social governance}

The legal construction of public participation lags behind the economic and social development. At present, throughout the public participate in social governance mode single, simple method, existing laws only hearings, seminars and public comment and other ways, relates 
to the field of mainly concentrated in the labor and social security, real estate, environmental protection, urban management, law enforcement environment improvement and the vital interests of citizens related aspects. One of the theoretical circle hot topic is how from simple representative democracy to the representative with the participation of the mixed type of democratic transition, citizen politics and democratic participation. Which is a very important system, is to get rid of the current management system of the government based, to achieve democratic participation in social governance system. Public participation in social governance requirements of public in law is not only a selected instead of his "speak", the law enforcement of public power "suffered in silence", but also in a set of laws have the opportunity to personally "speak", in the operation of the law have the opportunity to participate in opinion. Therefore, only to strengthen the public participation in the legal system of social governance, as soon as possible to improve the legal system of public participation in social governance, in order to protect the public from the fundamental legal and orderly participation in social governance.

Public participation in social governance is restricted by the traditional mode of social governance. At this stage, people's ideology, social structure and public interest demands increasingly diversified. The social development situation has appeared the new situation, which has put forward the new request to the government management society. Now the social governance is not only required to take good care of society, but also to mobilize the enthusiasm of all aspects of society, increase the vitality of social development, and create a harmonious and orderly social environment. China is a socialist country, our social governance philosophy should maximize the mobilization of social member's enthusiasm, the maximum increase harmonious factors, and build the a socialist harmonious society. Sometimes the social implement necessary "tube" and "pressure" is indispensable, but at the same time, we also want to see the "tube" and the "pressure" can only is local behavior, expediency. If the whole society is a long-term "tube" and the "pressure", when the "tube" and the "pressure" beyond social bearing degrees, a society cannot get long-term stability, not to mention the harmonious development, even also planted a tumultuous destruction of seeds. In order to build a socialist harmonious society, to promote the harmonious development of society, we need to establish a smooth channel of interest expression and security mechanism. Because in the process of interest expression and integration of the interests of the inevitable there will be a variety of social conflicts, if not promptly resolve these contradictions, may cause social unrest. So we want to maintain social stability of the rigid and flexible, rigid social stability effect is obvious, but also limited, elastic stability is the essence of social stability. Therefore, only to break the shackles of the traditional social governance system, the public participation in social governance in order to achieve real results.

The transformation of government functions is not in place, ignoring the role of public participation in social governance. The government still bear a lot of social management and public service functions, government of society of centralized leadership remains, of the government's social management of too many dead, lack of social vitality. Public participation in social management to break through the constraints of the government's social management functions, the promotion of social governance and construction of a harmonious society, only to change past government swept all of the administrative concept, correctly handle the relationship between social governance of multiple subjects, promote the government administrative system reform, change the government swept over the pattern of social public affairs, gradually improve the social self management, self development mechanism to for social forces to provide a broad space for development to the self management ability of society formation and improve and establish the realistic foundation. The transformation of government functions and cannot is simply 
the existing administration system for minor repairs, also not the government functions of the general regulation, but a transfer of government functions, transferring power. In essence, it is the reconstruction of the national and social interests of the pattern of, hence the need for a greater determination and courage. If you can not break the government centralized the shackles of administrative management, public decision-making scientific, rationality, it is difficult to guarantee, reform is difficult to have a substantive breakthrough. So in terms of the transformation of government functions is not in place, public participation to attention, to break the government to public participation in social governance constraints exist great resistance to the public it is difficult to really participate in social governance practice activity to, the development of social governance of public power is full of thorns.

In short, we must clearly recognize mechanism of public participation in social governance still exist public participation in social governance system construction is lagging behind, public participation in social governance by the government's social management constraints and lack of protection of public participation in the legal system of social governance and other issues. Only by solving these problems, can we overcome the difficulties faced by the public in the process of participation in social governance, in order to create conditions for the further development of China's public participation in social governance.

\section{References}

[1] Zheng Hangsheng. Toward a more talk about the governance of society: social construction and social management [M]. Renmin University of China press, 2006.

[2] Wang Lijing. Study on institutional study of Chinese citizen participation [M]. Wuhan University press, 2011.

[3] Cai Dingjian. Public participation: the construction of the system of risk society [M]. legal press, 2009

[4] Zheng Weiwei. New media and citizen participation in an orderly [J]. Journal of Huazhong University of Science and Technology (SOCIAL SCIENCE EDITION). 2012.1.

[5] Jiang Mingan. Public participation and administrative rule of law [J]. China Law.2004.2. 